\title{
PROFIL METABOLIT SEKUNDER, AKTIVITAS ANTIBAKTERI DAN KOMPOSISI SENYAWA YANG TERKANDUNG DALAM EKSTRAK METANOL TERIPANG Stichopus horrens
}

\section{PROFILE OF SECONDARY METABOLITES, ANTIBACTERIAL ACTIVITY AND COMPOUND COMPOSITION IN THE METHANOLIC EXTRACT OF SEA CUCUMBER Stichopus horrens}

\author{
Abdullah Rasyid $^{1 *}$, Tri Wahyuningsih ${ }^{2}$, dan Ardi Ardiansyah ${ }^{1}$ \\ ${ }^{1}$ Pusat Penelitian Oseanografi LIPI \\ ${ }^{2}$ Fakultas MIPA Universitas Negeri Jakarta \\ *E-mail: a.rasyid.qf@gmail.com
}

\begin{abstract}
Stichopus horrens is one of the sea cucumber species that has the potential to be developed as a source of antibacterial from the sea. Samples of the sea cucumber $\underline{S}$. horrens used in this study collected from the Ratai bay waters, Lampung in April 2016. This study aims to determine the type of secondary metabolites, antibacterial activity and compound composition containing in the methanol extract of sea cucumber S. horrens. Extraction method used in this study was the maceration method using methanol. Identification of secondary metabolites by observation of color reactions, precipitation, and foam. The method used to antibacterial activity test was the agar diffusion method, while identification of the composition of compounds performed with Gas Chromatography-Mass Spectroscopy (GC-MS) method. The results showed that the type of secondary metabolites contained

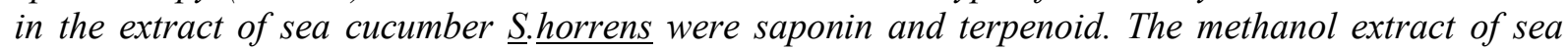
cucumber $\underline{S}$. horrens showed antibacterial activity against all bacterial test. Based on result of showed 7 compounds have a similarity index same or more than 90\%. Compounds consist of 9,12octadecadienoic, hexadecanoic acid, 3,8-di-tert-butyl-1,10-phenanthroline, 1,13-tetradecadiene and 6,9-pentadecadien-1-ol. The compound with the biggest abundance was 6,9-pentadecadien-1-ol (25.48\%) and retention time was 18.597 minutes.
\end{abstract}

Keywords: antibacterial, GC-MS, Lampung, secondary metabolite, Stichopus horrens

\begin{abstract}
ABSTRAK
Stichopus horrens merupakan salah satu jenis teripang yang memiliki potensi untuk dikembangkan sebagai sumber bahan antibakteri dari laut. Sampel teripang $S$. horrens yang digunakan dalam penelitian ini berasal dari perairan Teluk Ratai Lampung pada bulan April 2016. Penelitian ini bertujuan untuk menentukan jenis metabolit sekunder, aktivitas antibakteri dan komposisi senyawa yang terkandung dalam ekstrak metanol teripang Stichopus horrens. Metode ekstraksi yang digunakan adalah metode maserasi menggunakan pelarut metanol. Identifikasi metabolit sekunder dengan pengamatan reaksi warna, pengendapan dan buih. Metode yang digunakan untuk uji aktivitas antibakteri adalah metode difusi agar, sedangkan analisa komposisi senyawa menggunakan Kromatografi Gas - Spektroskopi Massa (KG-SM). Hasil identifikasi golongan metabolit sekunder menunjukkan bahwa ekstrak metanol teripang $S$. horrens mengandung steroid dan saponin. Hasil uji aktivitas antibakteri menunjukkan bahwa ekstrak metanol teripang $S$. horrens hanya memiliki aktivitas antibakteri terhadap Bacillus subtilis dan Vibrio eltor. Berdasarkan hasil penelitian dapat disimpulkan bahwa terdapat 7 senyawa dengan indeks kemiripan sama atau lebih besar dari 90\%. Senyawa tersebut terdiri dari asam 9,12-oktadekadienoat, asam heksadekanoat, 3,8-di-tert-butil-1,10-fenantrolin, 1,13tetradekadiena dan 6,9-pentadekadien-1-ol. Senyawa dengan kelimpahan terbesar adalah 6,9pentadekadien-1-ol yaitu 28,48\% dengan waktu retensi 18,597 menit.
\end{abstract}

Kata kunci: antibakteri, KG-SM, Lampung, metabolit sekunder, Stichopus horrens 


\section{PENDAHULUAN}

Bakteri adalah organisme bersel tunggal yang hidup bebas dan mampu bereproduksi sendiri tetapi menggunakan biota inang sebagai media untuk mendapatkan makanan (Corwin, 2007). Bakteri dapat berkembangbiak pada suhu yang hangat. Tidak mengherankan jika di Indonesia yang beriklim tropis banyak bakteri yang berkembangbiak dan menimbulkan berbagai penyakit. Contoh bakteri yang dapat menimbulkan penyakit di antaranya bakteri Bacillus subtilis, Escherichia coli, Staphylococcus aureus, dan Vibrio choleraee, bakteri tersebut dapat menginfeksi saluran pencernaan.

Data Kemenkes (2013) menyebutkan bahwa antara tahun 2000 sampai 2010 telah terjadi kecenderungan kenaikan penderita diare. Bahkan pada tahun 2010 infeksi diare di Indonesia dinyatakan sebagai kejadian luar biasa (KLB) pada 33 kecamatan dengan jumlah penderita 4204 dengan kematian 73 orang. Meningkatnya penderita diare menyebabkan penggunaan antibiotik juga meningkat. Sebagian besar antibiotik yang terbuat dari senyawa sintetik yang jika dikosumsi secara terus menerus dapat menyebabkan efek samping dan bakteri menjadi resisten. Berbagai upaya mulai dilakukan untuk mengurangi dampak negatif penggunaan antibiotik sintetik seperti pengembangan riset tentang senyawa metabolit sekunder yang berpotensi sebagai antibakteri dari bahan alam.

Indonesia memiliki sumber daya alam yang sangat melimpah khususnya yang berasal dari laut yang belum dikembangkan dan dimanfaatkan secara maksimal, padahal berbagai bahan bioaktif yang terkandung dalam biota laut seperti protein, omega-3, vitamin dan hormon sangat bermanfaat bagi kesehatan (Roihanah et al., 2012). Salah satu sumber daya alam dari laut adalah teripang. Teripang memiliki potensi biofarmaka dan makanan kesehatan dengan kandungan gizi yang tinggi terutama protein (Karnila, 2011).
Sekitar 1.135 spesies teripang yang dikenal di seluruh dunia diperkirakan mencapai 257 spesies ditemukan di Indonesia (Kordi, 2010). Teripang diketahui mengandung vitamin, kalsium, besi, magnesium, zink, kondroitin sulfat dan saponin glikosida (Esmat et al., 2012). Teripang juga dilaporkan memiliki aktivitas antiangiogenik, antikanker, antikoagulan, antihipertensi, anti inflamasi, antimikroba, antioksidan, antitrombotik, antitumor dan penyembuhan luka (Bordbar et al., 2011).

Stichopus horrens merupakan salah satu jenis teripang yang umum dijumpai di perairan Indonesia. Sampai saat ini penelitian tentang potensi bioaktivitas teripang $S$. horrens asal perairan Teluk Ratai Lampung belum dilakukan. Tujuan penelitian ini adalah untuk menentukan golongan senyawa metabolit sekunder, aktivitas antibakteri dan komposisi senyawa yang terkandung dalam ekstrak teripang $S$. horrens serta potensi pemanfaatannya sebagai salah satu sumber alternatif bahan antibakteri dari laut.

\section{METODE PENELITIAN}

\subsection{Bahan Penelitian}

Teripang Stichopus horrens sebanyak 3 individu dengan berat total 720 gram basah dikumpulkan dari perairan Teluk Ratai, Lampung pada posisi geografis $05^{\circ} 33,706^{\prime}$ Lintang Selatan dan $105^{\circ} 16,220^{\prime}$ Bujur Timur dengan kedalaman sekitar 2-3 meter. Sampel teripang dibersihkan dari kotoran dan pasir yang menempel dengan air laut, kemudian dibuang isi perutnya. Daging teripang yang telah bersih dimasukkan ke dalam kantong plastik yang telah diberi label lalu disimpan dalam cool box untuk selanjutnya dibawa ke Laboratorium Produk Alam Laut, Pusat Penelitian Oseanografi LIPI, Jakarta.

Bahan kimia yang digunakan dalam penelitian ini terdiri dari metanol $\left(\mathrm{CH}_{3} \mathrm{OH}\right)$, pereaksi Mayer, pereaksi Dragendrof, pereaksi Libermann-Burchard, asam sulfat $\left.\mathrm{H}_{2} \mathrm{SO}_{4}\right)$, amoniak $\left(\mathrm{NH}_{3}\right)$, serbuk magnesium 
$(\mathrm{Mg})$, amil alcohol $\left(\mathrm{C}_{5} \mathrm{H}_{12} \mathrm{O}\right)$, asam klorida $(\mathrm{HCl})$, asam asetat anhidrida $\left(\mathrm{C}_{3} \mathrm{H}_{6} \mathrm{O}_{5}\right)$, besi (III) klorida $\left(\mathrm{FeCl}_{3}\right)$, mueller hinton broth, mueller hinton agar, dimetilsulfoksida (DMSO), antibiotik siprofloksasin dan antibiotik tetrasiklin. Sedangkan bakteri uji yang digunakan terdiri dari Staphylococcus aureus (ATCC 25923), Bacillus subtilis (ATCC 6633), Escherichia coli (ATCC 25922) dan Vibrio cholerae.

\subsection{Ekstraksi Sampel}

Sampel teripang Stichopus horrens sebanyak 610 g yang sudah dipotong kecilkecil (sekitar $0,5 \mathrm{~cm} \quad \mathrm{x} \quad 0,5 \mathrm{~cm}$ ) dan dikeringanginkan dimaserasi dengan $1 \mathrm{~L}$ metanol. Proses maserasi dilakukan selama 3 hari dan setiap hari dilakukan pengadukan. Setelah 3 hari dilakukan penyaringan dan teripang direndam kembali dengan metanol yang baru. Proses maserasi dihentikan sampai diperoleh filtrat yang bening. Semua filtrat yang diperoleh digabungkan dan diiuapkan dengan rotary evaporator pada suhu $40^{\circ} \mathrm{C}$ sampai diperoleh ekstrak yang kental.

\subsection{Uji Metabolit Sekunder}

Ekstrak metanol teripang Stichopus horrens sebanyak $1 \mathrm{~g}$ ditambahkan $20 \mathrm{~mL}$ akuades, kemudian dipanaskan selama 5 menit. Larutan tersebut diambil sebanyak 10 $\mathrm{mL}$ dan dimasukkan ke dalam tabung reaksi dalam keadaan panas. Tabung dikocok dengan kuat selama 10 detik. Jika busa yang terbentuk stabil setinggi $1-10 \mathrm{~cm}$ selama 10 menit dan tidak hilang pada saat ditambahkan asam klorida $2 \mathrm{~N}$ menunjukkan adanya saponin (Harbone, 2006).

Ekstrak metanol teripang $S$. horrens sebanyak $1 \mathrm{~g}$ ditambahkan $10 \mathrm{~mL}$ kloroform-amoniak (9:1), lalu ditambahkan asam sulfat $1 \mathrm{M}$ sebanyak 20 tetes dan dikocok. Terbentuk dua lapisan dimana lapisan atas merupakan lapisan asam dan lapisan bawah merupakan lapisan kloroform. Lapisan asam dipipet dan dimasukkan ke dalam 2 buah tabung reaksi. Tabung reaksi pertama ditambahkan pereaksi Mayer, sedangkan tabung reaksi kedua ditambahkan pereaksi Dragendorf. Terbentuknya endapan putih pada tabung reaksi pertama dan endapan merah-jingga pada tabung reaksi kedua menandai adanya alkaloid (Harbone, 2006).

Ekstrak metanol teripang $S$. horrens sebanyak $1 \mathrm{~g}$ ditambahkan $25 \mathrm{~mL}$ akuades dan dipanaskan selama 5 menit. Larutan sampel dimasukkan ke dalam 2 buah tabung reaksi. Tabung reaksi pertama ditambahkan sedikit serbuk magnesium, $1 \mathrm{~mL}$ asam klorida pekat dan $1 \mathrm{~mL}$ amil alkohol. Terbentuknya warna merah pada lapisan amil alkohol menandakan adanya senyawa flavonoid. Tabung reaksi kedua ditambahkan larutan $\mathrm{FeCl}_{3} 1 \%$ dan bila terbentuk warna biru atau biru-ungu menandakan adanya senyawa fenolik (Harbone, 2006).

Ekstrak metanol teripang $S$. horrens sebanyak $1 \mathrm{~g}$ ditambahkan dengan $2 \mathrm{~mL}$ kloroform dalam tabung reaksi dan digerus, kemudian cairan sampel diteteskan ke dalam plat tetes dan dibiarkan sampai kering. Lalu sampel ditambahkan dengan 1 tetes pereaksi Liebarmann-Burchard. Terbentuknya warna merah menandakan adanya senyawa triterpenoid dan terbentuknya warna biru atau ungu menandakan adanya senyawa steroid (Harbone, 2006).

\subsection{Uji Aktivitas Antibakteri}

Ekstrak metanol teripang Stichopus horrens dilarutkan dalam dimetil sulfoksida (DMSO) dengan variasi konsentrasi 20.000 ppm, $10.000 \mathrm{ppm}, 5.000 \mathrm{ppm}, 2.500 \mathrm{ppm}$, $1.250 \mathrm{ppm}, 625 \mathrm{ppm}, 312,5 \mathrm{ppm}, 156,25$ ppm dan 78,125 ppm. Sampel sebanyak 15 $\mu \mathrm{L}$ diteteskan pada paper disc kemudian dikeringanginkan. Paper disc antibiotik digunakan sebagai kontrol positif, sedangkan paper disc dari DMSO digunakan sebagai kontrol negatif. Cotton buds steril dicelupkan ke dalam suspensi bakteri uji dan digoreskan ke petri yang berisi media mueller hinton agar. Semua paper disc yang telah ditetesi sampel diletakkan di atas permukaan media 
muller hinton agar yang telah dtumbuhi bakteri dan diinkubasi selama 24 jam pada suhu $37^{\circ} \mathrm{C}$. Diameter zona bening diukur menggunakan jangka sorong.

\subsection{Analisis Kromatografi Gas- Spektroskopi Massa}

Analisis jenis senyawa yang terkandung dalam ekstrak metanol teripang Stichopus horrens menggunakan Kromatografi Gas-Spektroskopi Massa (GC-MS). GC-MS yang digunakan memiliki spesifikasi sebagai berikut: Aglient Technologies 7890 Gas Chromatogaph with Auto Sampler and 5975 Mass Selective Detector (GC-MS) and Chemstation data system. Jenis kolom yang digunakan adalah HP Ultra 2 Capilary Column Length (m) 30 x 0,25 (mm) LD x $0,25(\mu \mathrm{m})$. Pelaksanaan analisa dilakukan di Laboratorium Kesehatan Daerah Khusus Ibukota Jakarta.

\section{HASIL DAN PEMBAHASAN}

\subsection{Hasil Ekstraksi Teripang Stichopus horrens}

Ekstrak metanol yang diperoleh selama proses maserasi sebanyak $3.300 \mathrm{~mL}$. Semua hasil maserasi dievaporasi dengan rotary evaporator dan diperoleh ekstrak pekat berbentuk pasta sebesar 22,2105 g.

\subsection{Hasil Uji Metabolit Sekunder Teripang Stichopus horrens}

Uji metabolit sekunder dilakukan untuk mengetahui golongan senyawa metabolit sekunder yang terkandung di dalam teripang Stichopus horrens. Hasil uji metabolit sekunder teripang $S$. horrens segar dan ekstrak metanol teripang $S$. horrens ditunjukkan pada Tabel 1.

Berdasarkan hasil uji metabolit sekunder, teripang $S$. horrens segar mengandung senyawa saponin, sedangkan ekstrak metanol teripang $S$. horrens mengandung senyawa saponin dan triterpenoid. Hasil positif uji saponin pada teripang segar dan ekstrak metanol ditandai terbentuknya busa yang stabil setelah penambahan $\mathrm{HCl}$ pekat. Hasil positif uji triterpenoid pada ekstrak metanol ditandai terbentuknya warna merah keunguan setelah penambahan anhidrida asam asetat dan asam sulfat pekat.

Tabel 1. Hasil analisis golongan metabolit sekunder teripang segar dan ekstrak metanol teripang Stichopus horrens.

\begin{tabular}{lcc}
\hline \multicolumn{1}{c}{ Metabolit sekunder } & $\begin{array}{c}\text { Teripang } \\
\text { Segar }\end{array}$ & $\begin{array}{c}\text { Ekstrak } \\
\text { Metanol }\end{array}$ \\
\hline Alkaloid & - & - \\
Flavonoid & - & - \\
Fenolik & - & - \\
Saponin & + & + \\
Steroid & - & - \\
Triterpenoid & - & + \\
Keterangan : & $-=$ tidak teridentifikasi \\
& $+=$ teridentifikasi
\end{tabular}

\subsection{Aktivitas Antibakteri}

Uji aktivitas antibakteri dilakukan untuk mengetahui potensi antibakteri ekstrak metanol teripang $S$. horrens terhadap bakteri Bacillus subtilis, Escherichia coli, Staphylococus aureus, dan Vibrio cholerae. Hasil analisis menunjukkan bahwa bakteri Bacillus subtilis dapat dihambat oleh ekstrak metanol dengan konsentrasi terkecil 6,25 ppm dengan zona bening yang terbentuk sebesar 7,90 $\mathrm{mm}$ atau $41,15 \%$ terhadap tertrasiklin dan $36,57 \%$ terhadap siprofloksasin. Pada konsentrasi terbesar (20.000 ppm), ekstrak metanol memiliki aktivitas antibakteri terhadap bakteri $B$. subtilis sebesar 9,52 $\mathrm{mm}$ atau 49,58\% terhadap tetrasiklin dan $44,07 \%$ terhadap siprofloksasin.

Bakteri $S$. aureus dapat dihambat oleh ekstrak metanol dengan konsentrasi terkecil 625 ppm dengan zona bening yang terbentuk sebesar $7,35 \mathrm{~mm}$ atau $34,43 \%$ terhadap tetrasiklin dan $38,48 \%$ terhadap siprofloksasin. Pada konsentrasi terbesar $(20.000$ 
ppm), ekstrak metanol memiliki aktivitas antibakteri terhadap bakteri $S$. aureus sebesar $10,85 \mathrm{~mm}$ atau $50,82 \%$ terhadap tetrasiklin dan 56,51\% terhadap siprofloksasin.

Bakteri E. coli dapat dihambat oleh ekstrak metanol dengan konsentrasi terkecil 156,25 ppm dengan zona bening yang terbentuk sebesar 7,35 $\mathrm{mm}$ atau 36,21\% terhadap tetrasiklin dan 30,75\% terhadap siprofloksasin. Pada konsentrasi terbesar (20.000 ppm), ekstrak metanol memiliki aktivitas antibakteri terhadap bakteri $E$. coli sebesar $10 \mathrm{~mm}$ atau 49,26\% terhadap tetrasiklin dan $41.84 \%$ terhadap siprofloksasin.

Bakteri $V$. cholerae dapat dihambat oleh ekstrak metanol dengan konsentrasi terkecil 156,25 ppm dengan zona bening yang terbentuk sebesar 7,45 $\mathrm{mm}$ atau $37,82 \%$ terhadap tetrasiklin dan 30,22\% terhadap siprofloksasin. Pada konsentrasi terbesar (20.000 ppm), ekstrak metanol memiliki aktivitas antibakteri terhadap bakteri $V$. cholerae $11,15 \mathrm{~mm}$ atau $56,59 \%$ terhadap tetrasiklin dan $45,23 \%$ terhadap siprofloksasin. Hasil uji antibakteri tersebut menunjukkan bahwa ekstrak metanol teripang $S$. horrens memiliki potensi antibakteri terbaik karena mampu menghambat bakteri $E$. coli dan $V$. cholerae dengan konsentrasi terkecil sebesar 156,25 ppm.

Kusuma et al. (2016) melaporkan bahwa teripang $S$ horrens yang berasal dari perairan Langkawi (Malaysia) memiliki aktivitas antibakteri terhadap bakteri Salmonella typhi dan S. paratyphi. Beberapa jenis teripang genus Stichopus juga dilaporkan memiliki aktivitas antibakteri, terhadap bakteri $S$. aureus, B. subtilis dan $V$. eltor seperti teripang $S$. hermanii (Rasyid, 2012) dan Stichopus sp. (Rasyid, 2013). Teripang $S$. hermanii, $S$. variegatus dan $S$. chloronatus juga dilaporkan memiliki aktivitas antibakteri terhadap bakteri Escherichia coli, Psedomonas sp., $V$. volnivica dan Enterococcus faecalis (Pringgenies, 2013; Tamara et al., 2015). Teripang $S$. badionatus dilaporkan memiliki aktivitas antibakteri terhadap bakteri $S$. aureus (Mariana, 2009). Teripang S. ocellatus dilaporkan memiliki aktivitas antibakteri terhadap bakteri $V$. eltor dan $E$. coli (Rasyid, 2014). Sedangkan teripang $S$. noctivagus memiliki aktivitas antibakteri terhadap bakteri E. coli dan V. eltor (Rasyid, 2016).

Berdasarkan hasil analisis metabolit sekunder, teripang S. horrens mengandung triterpenoid dan saponin yang dapat menghambat pertumbuhan bakteri. Mekanisme triterpenoid sebagai antibakteri adalah bereaksi dengan porin atau pintu keluar masuknya senyawa pada membran luar dinding sel bakteri dengan membentuk ikatan kompleks. Kerusakan tersebut mengakibatkan permeabilitas dinding sel bakteri akan berkurang sehingga mengganggu keluar masuknya senyawa yang dibutuhkan bakteri dan mengakibatkan pertumbuhan bakteri terhambat dan mati (Cowan, 1999). Sedangkan mekanisme saponin bertindak sebagai antibakteri dengan cara menurunkan tegangan permukaan dinding sel sehingga mengganggu permeabilitas membran sel dan mengakibatkan kerusakan membran sel. Membran sel yang rusak akan mengakibatkan kebocoran dan kematian sel (Caulier et al., 2011).

Antibiotik siprofloksasin termasuk golongan quinolone dengan rumus molekul $\mathrm{C}_{17} \mathrm{H}_{18} \mathrm{FN}_{3} \mathrm{O}_{3}$. Siprofloksasin bersifat bakterisidal dan termasuk antibiotik dengan spektrum penggunaan yang luas. Siprofloksasin dapat menghambat pembentukan asam nukleat pada bakteri dengan cara menghambat enzim topoisomerase II (DNA gyrase) dan enzim topoisomerase IV yang berperan pada proses replikasi, transkripsi dan rekombinasi DNA (DrugBank, 2015). Penggunaan siprofloksasin terutama untuk mengatasi infeksi saluran pencernaan, infeksi saluran kemih, infeksi saluran pernafasan, infeksi kulit, dan demam tifoid. Bakteri yang dapat diatasi oleh antibiotik ini antara lain $S$. aureus, S. pneumonia, E. coli, B. subtilis dan B. cereus (Oliphant and Green, 2002). 
Tetrasiklin merupakan antibiotik yang dihasilkan oleh bakteri Streptomyces dari genus Actinobacteria dan termasuk antibiotik berspektrum luas yang aktif terhadap bakteri gram positif maupun bakteri gram negatif. Tetrasiklin memiliki rumus molekul $\mathrm{C}_{22} \mathrm{H}_{24} \mathrm{~N}_{2} \mathrm{O}_{8}$. Antibiotik ini bersifat bakteriostatik dalam menghambat sintesis protein pada bakteri dengan cara menghalangi penggabungan asam amino ke rantai peptida. Penggunaan antibiotik ini terutama dalam mengatasi infeksi saluran pencernaan, infeksi saluran pernapasan, infeksi kulit dan demam tipus. Bakteri yang dapat diatasi oleh antibiotik ini antara lain $V$. cholerae, E. coli, Moraxella catarrhalis, Streptococcus pneumoniae, Propionibacterium acnes dan $S$. pyogenes (DrugBank, 2015).

\subsection{Analisis Kromatografi Gas - Spektroskopi Massa (GC-MS)}

Analisis menggunakan GC-MS yang bertujuan untuk mengetahui senyawa apa saja yang terkandung dalam ekstrak metanol teripang Stichopus horrens. Analisis ini akan menghasilkan dua data yaitu data GC (Gas
Chromatography) berupa kromatogram yang menampilkan puncak-puncak senyawa yang terkandung dalam ekstrak metanol teripang S. horrens, dan data MS (Mass Spectroscopy) yang menunjukkan berat molekul dan struktur molekul pada tiap puncak. Setiap puncak yang muncul pada kromatogram GC menunjukkan satu molekul dan memiliki pola fragmentasi yang ditampilkan dalam spektra MS. Berdasarkan pola fragmentasi tersebut dapat diidentifikasi senyawa apa yang terkandung dalam sampel yang dianalisis.

Gambar 1 menunjukkan kromatogram GC-MS ekstrak metanol teripang $S$. horrens yang memiliki 7 puncak yang berarti terdapat 7 senyawa yang teridentifikasi dengan indeks kemiripan sama atau lebih besar dari 90\%. Senyawa tersebut terdiri dari asam 9,12-oktadekadienoat, asam heksadekanoat, 3,8-di-tert-butil-1,10fenantrolin, 1,13-tetradekadiena dan 6,9pentadekadien-1-ol (Tabel 2). Senyawa dengan kelimpahan terbesar adalah 6,9pentadekadien-1-ol yaitu $28,48 \%$ dengan waktu retensi 18,597 menit.

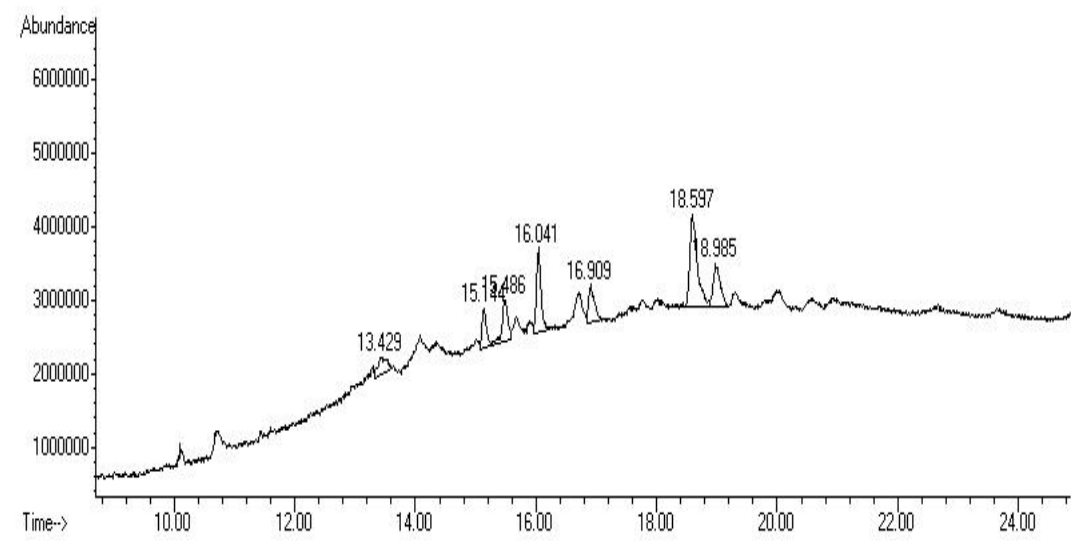

Gambar 1. Kromatogram hasil GC-MS ekstrak metanol teripang Stichopus horrens.

Tabel 2. Hasil analisa GC-MS ekstrak metanol teripang Stichopus Horrens.

\begin{tabular}{cccccc}
\hline No & $\begin{array}{c}\text { Waktu } \\
\text { Retensi } \\
\text { (menit) }\end{array}$ & $\begin{array}{c}\text { Massa } \\
\text { Molekul }\end{array}$ & \multicolumn{1}{c}{ Senyawa } & $\begin{array}{c}\text { Indeks } \\
\text { kemiripan (\%) }\end{array}$ & Area (\%) \\
\hline 1 & 13,249 & 280,24 & asam 9,12-Oktadekadienoat & 99 & 6,32 \\
2 & 15,144 & 270,26 & metil heksadekanoat & 93 & 6,94 \\
\hline
\end{tabular}




\begin{tabular}{ccclcc}
\hline No & $\begin{array}{c}\text { Waktu } \\
\text { Retensi } \\
\text { (menit) }\end{array}$ & $\begin{array}{c}\text { Massa } \\
\text { Molekul }\end{array}$ & \multicolumn{1}{c}{ Senyawa } & $\begin{array}{c}\text { Indeks } \\
\text { kemiripan (\%) }\end{array}$ & Area (\%) \\
\hline 3 & 15,486 & 292,19 & 3,8-di-tert-butil-1,10-fenantrolin & 90 & 9,95 \\
4 & 16,041 & 194,20 & 1,13-tetradekadiena & 93 & 16,13 \\
5 & 16,909 & 280,24 & asam 9,12-Oktadekadienoat & 93 & 9,25 \\
6 & 18,597 & 224,21 & 6,9-pentadekadien-1-ol & 95 & 28,48 \\
7 & 18,985 & 280,24 & asam 9,12-Oktadekadienoat & 98 & 12,09 \\
\hline
\end{tabular}

Asam 9,12-Oktadekadienoat atau asam linoleat dilaporkan memiliki aktivitas antibakteri terhadap Bacillus subtilis dan Staphylococcus aureus (Dilika et al., 2000; Yff et al., 2002)) dan Escherichia coli (Yff et al., 2002), Senyawa metil heksadekanoat atau asam palmitat dilaporkan memiliki aktivitas antibakteri terhadap bakteri $S$. aureus (Ivanova et al., 2017). Senyawa 6,9pentadekadien-1-ol juga dilaporkan memiliki aktivitas sebagai antibakteri (Sabithira and Udayakumar, 2017).

\section{KESIMPULAN}

Berdasarkan hasil penelitian dapat disimpulkan bahwa teripang Stichopus horrens asal perairan teluk Ratai Lampung mengandung triterpenoid dan saponin. Hasil analisis antibakteri menunjukkan teripang $S$. horrens memiliki potensi antibakteri terhadap Bacillus subtilis, Escherichia coli, Staphylococcus aureus dan Vibrio cholerae. Senyawa yang teridentifikasi dalam ekstrak metanol teripang $S$. horrens dengan kelimpahan terbesar adalah 6,9-pentadekadien-1-ol $(28,48 \%)$ dengan waktu retensi 18,597 menit.

\section{DAFTAR PUSTAKA}

Bordbar, S., F. Anwar, and N. Saari. 2011. High-value components and bioactives from sea cucumbers. Marine Dugs, 9:1761-1805. doi: 10.3390.md9101761.

Caulier, G., S.V. Dyck, P. Gerbaux, I. Eeckhaut and P. Flammang. 2011. Review of saponin diversity in sea cucumber belonging to the family
Holothuriidae. SPC Beche-de-mer Information Bulletin, 31:38-54.

Corwin, E.J. 2007. Buku saku patofisiologi. Edisi 3. Penerbit Buku Kedokteran EGC. Jakarta. $1031 \mathrm{hlm}$.

Cowan, M.M. 1999. Plant product as antimicrobial agents. Clin. Microbiol., 12(4): 564-582.

Dilika F., P.D. Bremner and J.J.M. Meyer. 2000, Antibacterial activity of linoleic and oleic acids isolated from Helichrysum pedunculatum: a plant used during circumcision rites. Fitoterapia, 71:450-452.

DrugBank. 2015. Tetracycline. http://www.drugbank.ca/drugs/DB 00759. [Retrived on 2 January 2018].

DrugBank. 2015. Ciprofloxacin. http://www.drugbank.ca/drugs/DB 00537. [Retrieved on 2 January 2018].

Esmat, A.Y., M.M. Said, A.A. Soliman, K.S.H. El-Masry, and E.A. Badiea. 2012. Bioactive compounds, antioxidant potential and hepatoprotective activity of sea cucumber (Holothuria atra) against thioacetamide intoxication in rats. Nutrion, 30:1-10. doi: 10 . 1016/j.nut.2012.06.004

Harbone. 2006. Metode fitokimia. Penerbit ITB. Bandung. $354 \mathrm{hlm}$.

Ivanova, E.P., S.H. Nguyen, Y. Guo, V.A. Baulin, H.K. Webb, V.K. Truong, J.V. Wandiyanto, C.J. Garvey, P.J. Mahon, D.E. Mainwaring and R.J. Crawford. 2017. Bactericidal activity 
of self-assembled palmitic and stearic fatty acid crystals on highly ordered pyrolytic graphite. Acta Biomater. 59: 148-157. doi: 10.1016/j.actbio.2017.07.004.

Karnila, R. 2011. Pemanfaatan komponen bioaktif teripang dalam bidang kesehatan. UNRI. Riua. $114 \mathrm{hlm}$.

Kemenkes. 2011. Situasi diare di Indonesia. Buletin Jendela Data dan Informasi Kesehatan, 2: 1-17.

Kordi, M.G.H. 2010. A to Z budidaya biota akuatik untuk pangan, kosmetik dan obat-obatan. Lily Publisher. Yogyakarta. $226 \mathrm{hlm}$.

Kusuma, A.S.W., T. Milanda, dan R. Ravee. 2016. Aktivitas antibakteri ekstrak dan fraksi teripang laut (Stichopus horrens) asal Langkawi, Malaysia terhadap Salmonella typhi ATCC 786 dan Salmonella paratyphi isolate klinis. Farmaka 14(2):47-57.

Mariana, N.S., M.A. Norfarrah, K.A.N.I. Nik, F.M. Yussof, and A. Arshad. 2009. Evaluating the antibacterial activity and in vivo assay of methanolic extract of Stichopus badionotus. International J. of Pharmacology, 5(3):228-231. doi:10.3923/ijp.2009.228.231.

Martoyo, J., N. Nugroho dan T. Winanto. 2006. Budidaya teripang. Penebar Swadaya. Jakarta. $77 \mathrm{hlm}$.

Oliphant, C.M. and G.M. Green. 2002. Quinolones: A comprehensive review. J. American Family Physician, 65:456-464.

Pringgenies, D. 2013. Antibacterial activity of sea cucumber harvested from Karimunjawa. Squalen Bulletin of Marine \& Fisheries Postharvest \& Biotechnology, 8(2): 87-94.

Rasyid, A. 2012. Identifikasi senyawa metabolit sekunder serta uji aktivitas antibakteri dan anti-oksidan ekstrak metanol teripang Stichopus hermanii. J. Ilmu dan Teknologi Kelautan Tropis, 4(2):360-
368. http://dx.doi.org/10.29244/jitkt .v4i2.7799.

Rasyid, A. 2013. Aktivitas antibakteri dan toksistas teripang Stichopus sp. J. Farmasi Indonersia,6 (4): 228-233.

Rasyid, A. 2014. Uji aktivitas antibakteri dan toksistas teripang Stichopus ocellatus asal perairan Lampung Selatan. Prosiding Seminar Nasional Ke-III Hasil-Hasil Penelitian Perikanan dan Kelautan. 435-440 hlm.

Rasyid, A. 2016. Aktivitas antibakteri, golongan metabolit sekunder dan komposisi senyawa yang terkandung dalam ekstrak teripang Stichopus noctivagus. Prosiding Pertemuan Ilmiah Tahunan XIII ISOI: $155-164$.

Roihanah, S. Sukoso dan Andayani. 2012. Aktivitas antibakteri ekstrak teripang Holuthuria sp. terhadap bakteri Vibrio harveyi secara in vitro. $J$. of Experiment Life Science, 2 (1): 1-5.

Sabithira, G. and R. Udayakumar. 2017. GC-MS analysis of methanolic extracts of leaf and stem of Marsilea minuta (Linn.). J. of Complementary and Alternative Medical Research, 3(1):1-13. doi: 10.9734/JOCAMR/2017/30871.

Tamara, R., L. Rochyani, dan F.B. Teguh. 2013. Daya hambat ekstrak teripang emas (Stichopus hermanii) terhadap bakteri Enterococcus faecalis. Denta, 9(1):36-46.

Yff B.T., K.I. Lindsey, M.B. Taylor, D.G. Erasmus, and A.K. Jäger. 2002. The pharmacological screening of Pentanisia prunelloides and the isolation of the antibacterial compound palmitic acid. $J$. Ethnopharmacol. 79: 101-107.

$\begin{array}{ll}\text { Diterima } & : \text { 23 Januari } 2018 \\ \text { Direview } & : \text { :07 Februari } 2018 \\ \text { Disetujui } & : 23 \text { Juli } 2018\end{array}$

